\title{
مسؤولية القانون الدولي في حماية الفئات الدينية المستضعفة
}

Doi: 10.23918/ilic2020.51

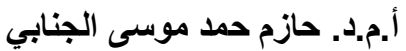 \\ كلية العلوم السياسية/جامعة مونى الموصن}

Email: hazim@uomosul.edu.iq

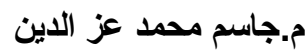

قسم القانون/ كلية اليرموك الجامعة الجين

Email:legal_men@yahoo.com

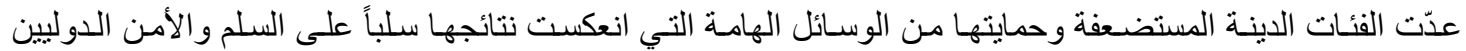

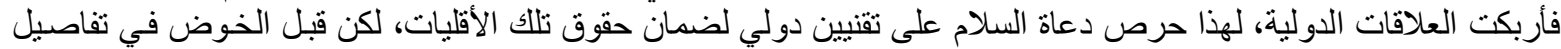

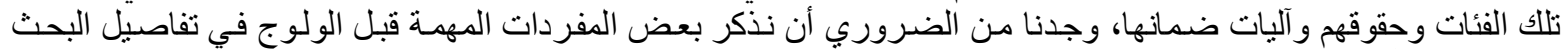

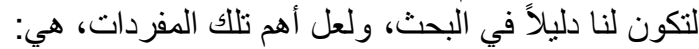

الأهمية: تبع من التكانة الدولية التي احتلتها حقوق الفئات الدئن الدينية المستضعفة، و هذا ما أثنارت له المحافل الدولية باستمر ار، كونها

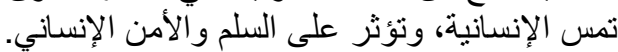

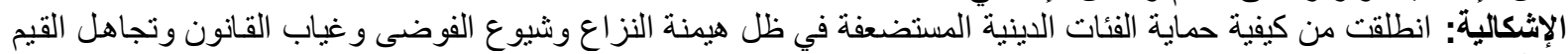

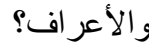
التسـاؤلات: تحساول هذه الدر اسـة الإجابـة عن السؤ ال الرئيس التـالي: هل تحمل القانون الدولي مسؤوليته في حمايـة الأقليات المستضعفة؟

وينبثق من هذا السؤال الأسئلة الفر عية التالية:

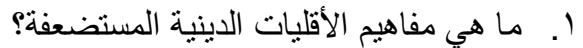

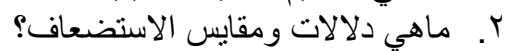

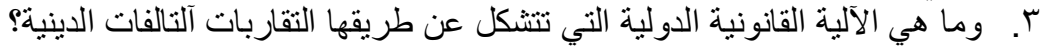

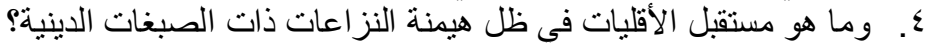

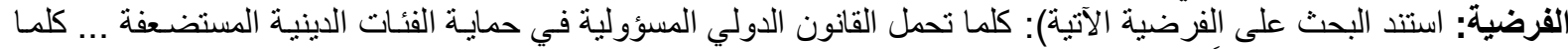

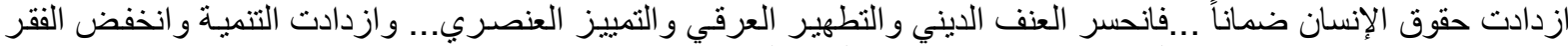

وتحققت البيئة الصالحة لتعايش الأديان)، وسيحاول الباحث الثان الثبات أو تفنيد تلك الك الفرضية.

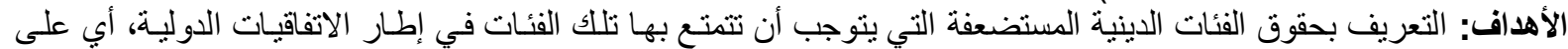

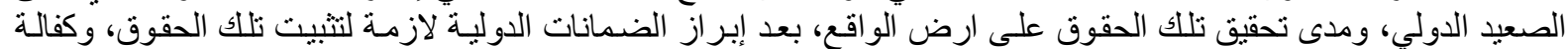

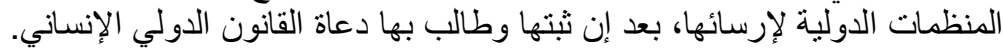
النطاق: يتحدد هذا البحث: الارسيا:

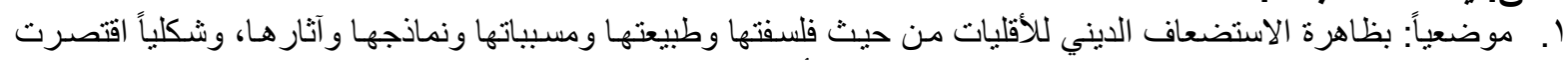

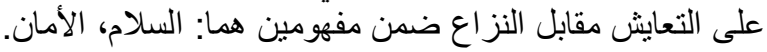

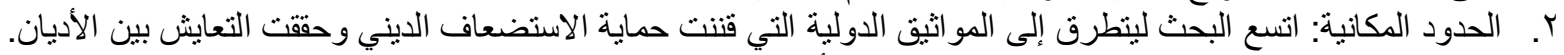

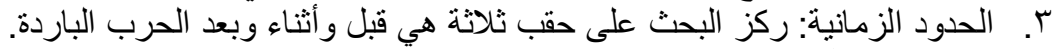

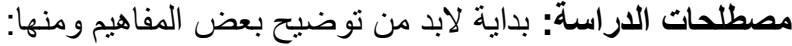

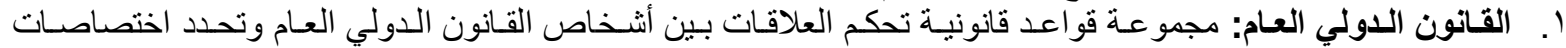
و التز امات كل منها. التولي. r. المسؤولية الدولية: نظام قانوني تلتزم بمقتضـاه الدولة التي تأتي عملاً غير مشروع طبقاً للقانون الدولي العـام بتعويض

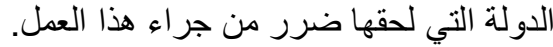

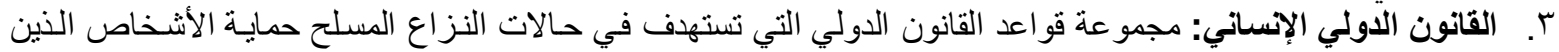

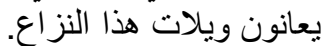

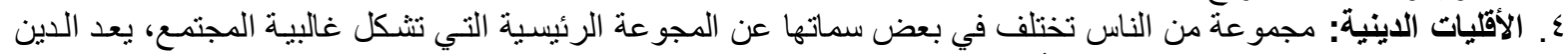

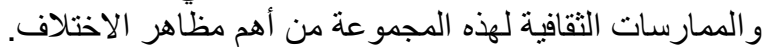

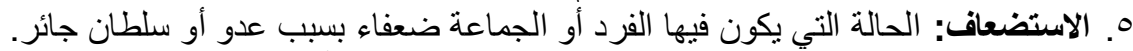

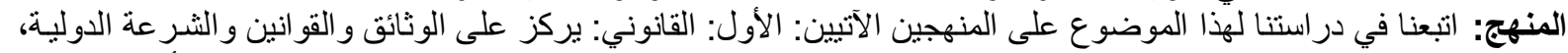

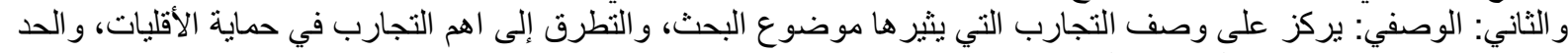
من انتهاكات حقوق الإنسان لصناعة السكلام. الهيكلية: ولدر اسة هذا الموضوق الانيان (مسؤولية القانون الدولي في حماية الفئات الدينية المستضعفة)، قسمناه إلى (مقدمة ومبحثين

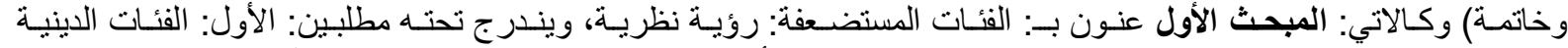

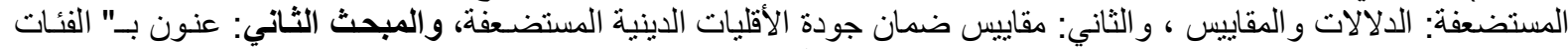
الدينية المستضعفة و المسؤولية الدولية، ونشطر إلى مطلبين : الأول: مسؤولية القانية التون الدوانية الدولي في حماية الفئات الدينية المستضعفة، و الثاني: مسؤولية القانون الدولي في حماية الأماكن الدينية المستضعفة، ولتكون خلاصنتا في الخاتمة . 
توطئة

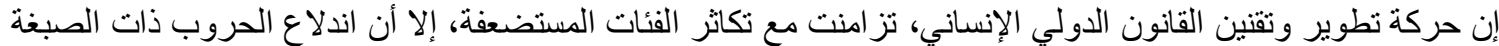

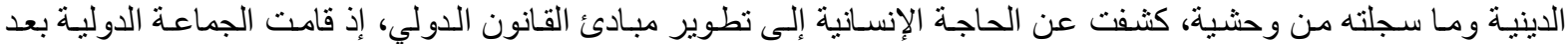

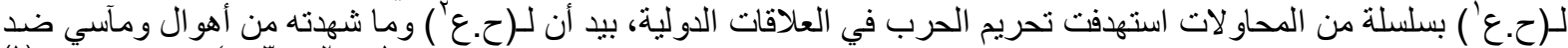

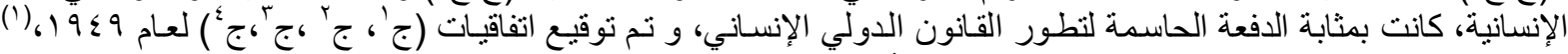

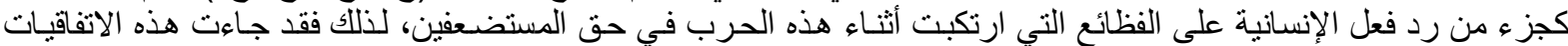

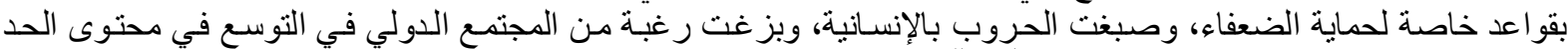

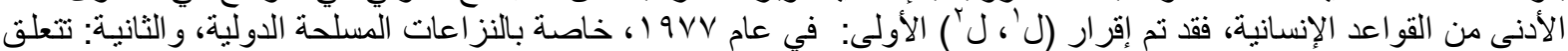

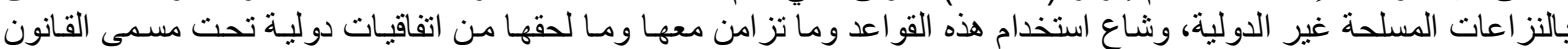

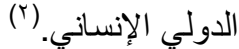
المبحث الأول و هذا ما دعانا إلى تقسيم البحث إلى مبحثين، وكالات

\section{الفئات الاينية المستضعفة: الدالات ولات والمقاييس}

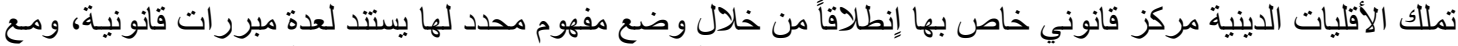

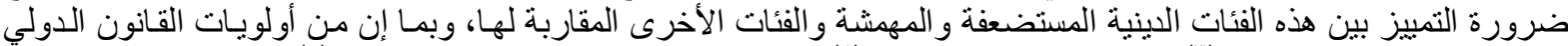

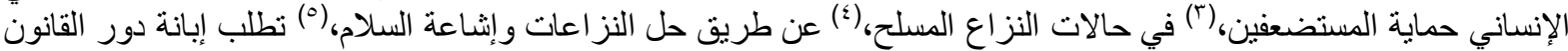

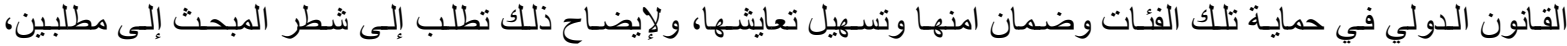

\section{المطلب الأول} وكالاتي: - n

\section{دلالات الفئات الاينية المستضعفة الأل المكة}

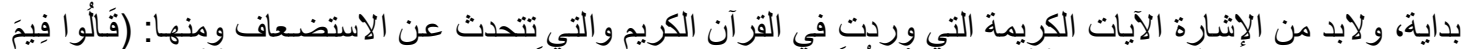

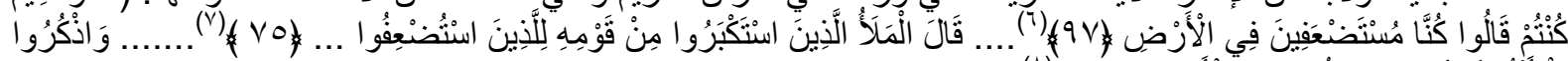

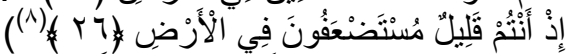

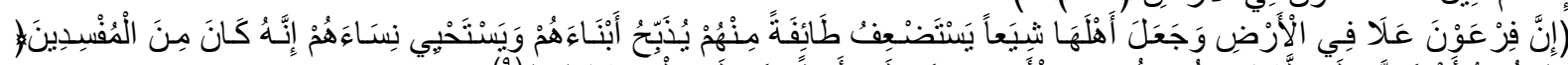

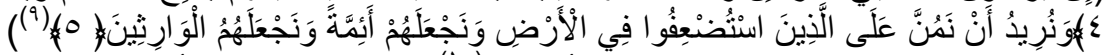

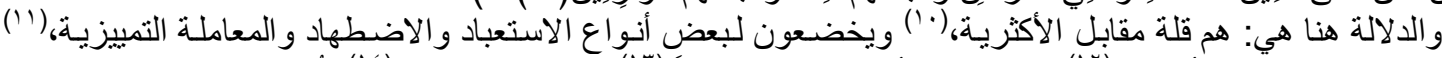

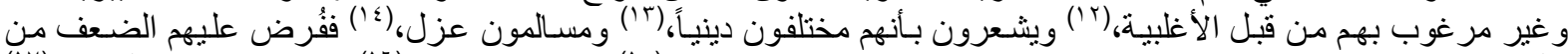

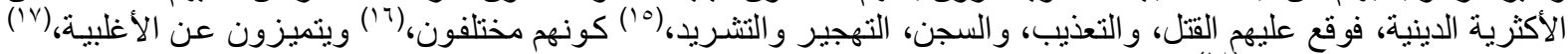

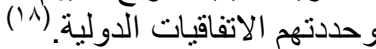

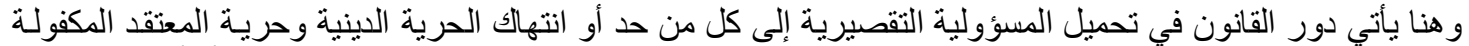

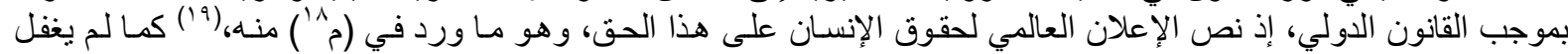

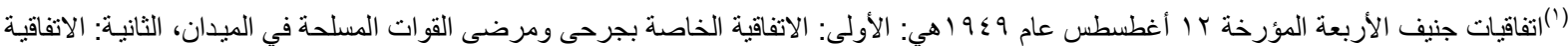

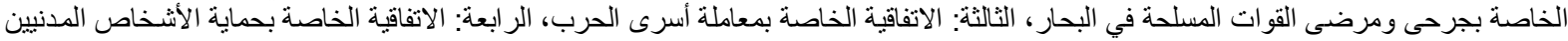

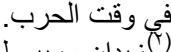

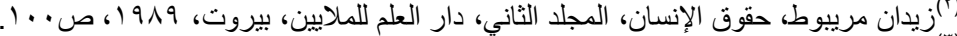

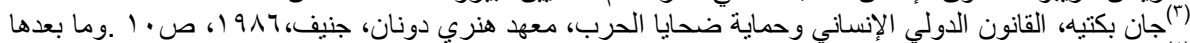

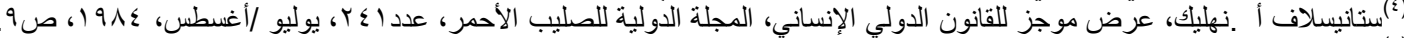

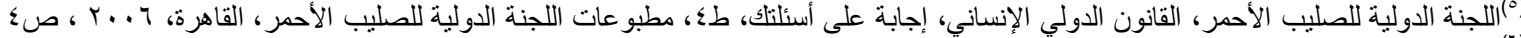

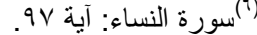

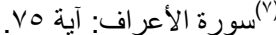

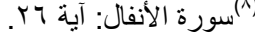

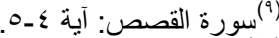

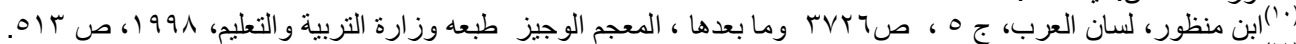

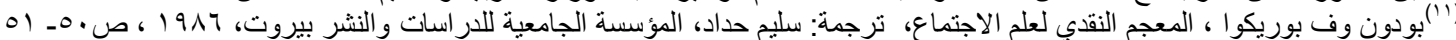

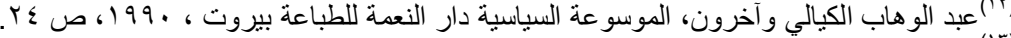

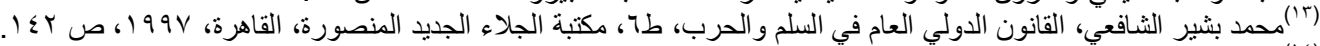

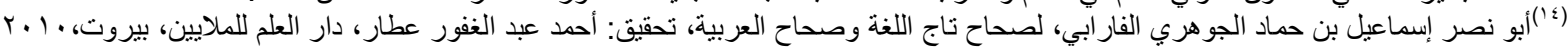
$1 \% 9 \cdot / \varepsilon$ 。

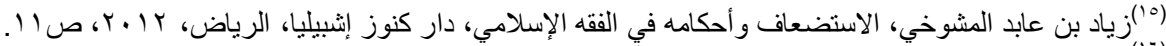

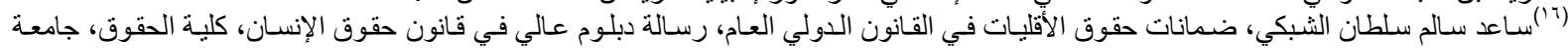

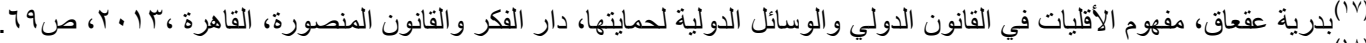

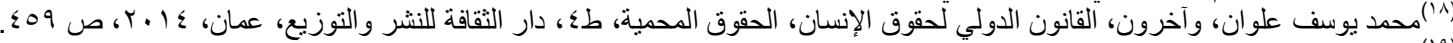

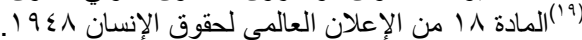




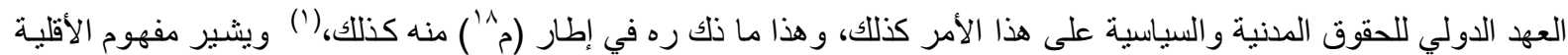

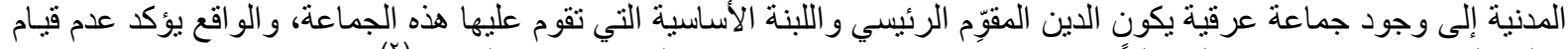

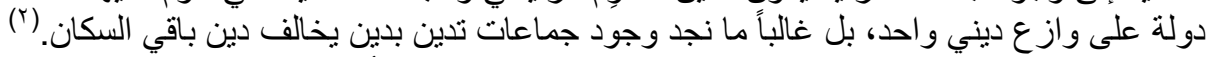

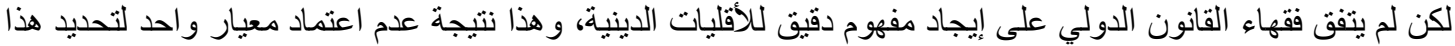

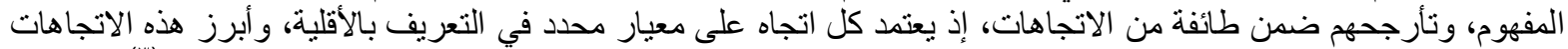

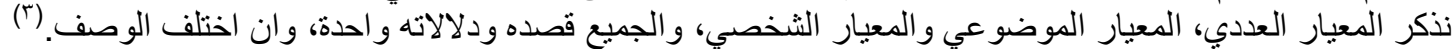
المطلب الثاني

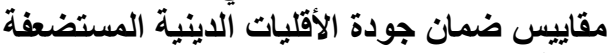

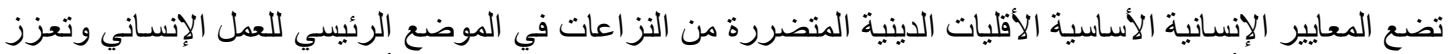

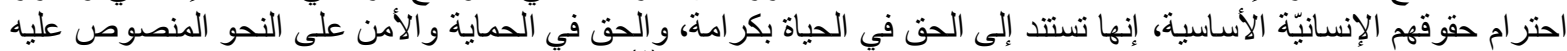

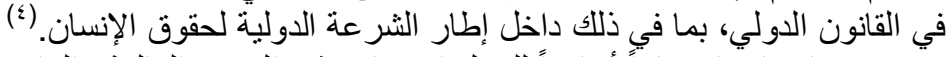

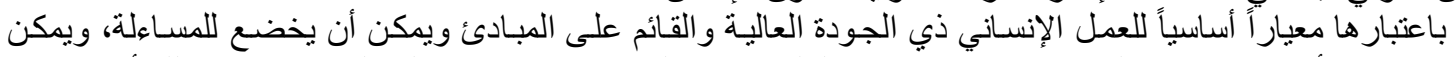

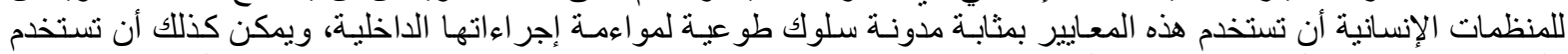

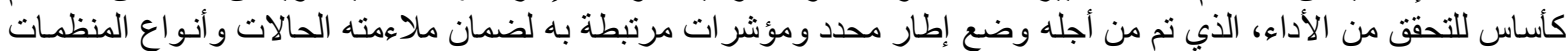
المختلفة.

( ) ( ) واختصار اً يمكن أجمال المو اثيق الدولية الحامية للفئات الدينية المستضعفة بالمخطط الاتي: رقم

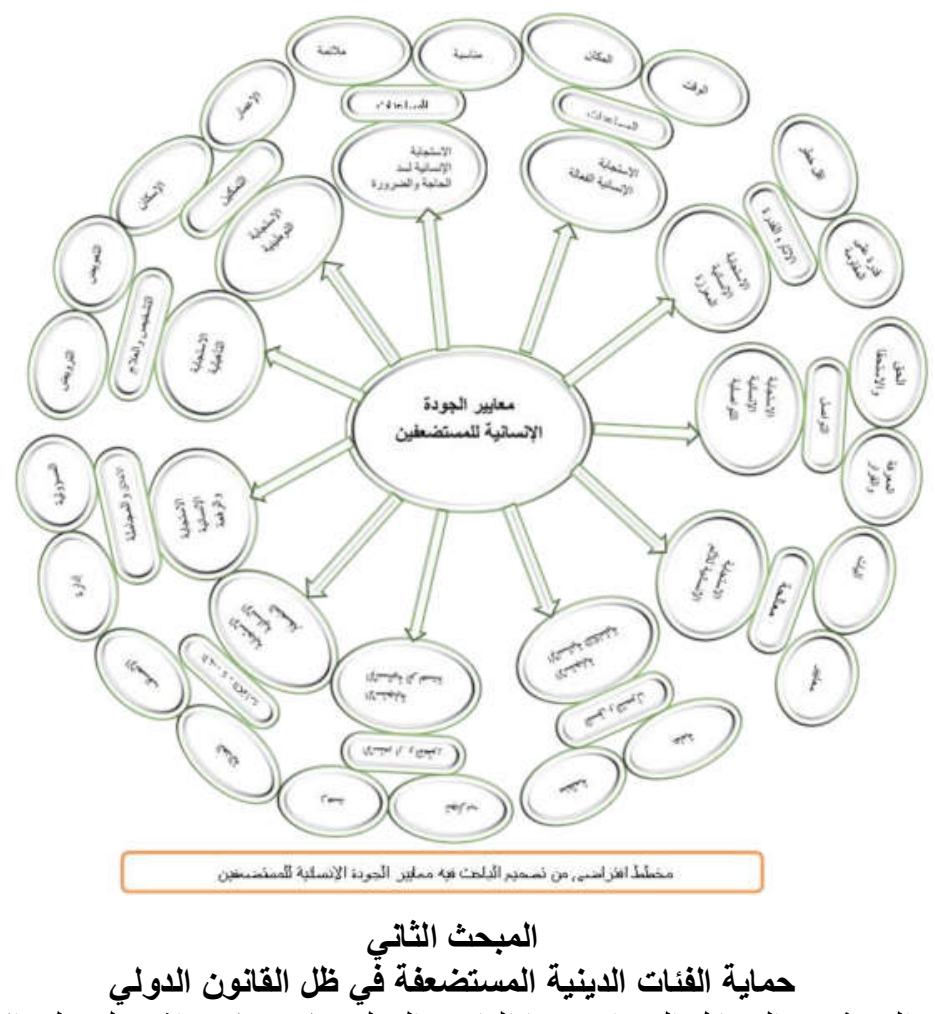

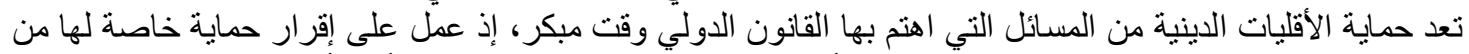

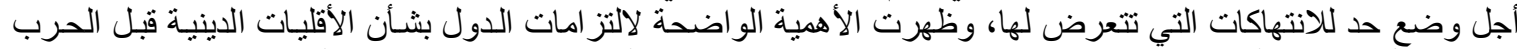

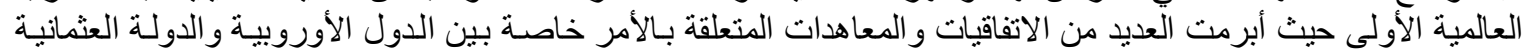

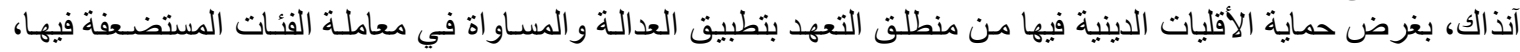
وتوالت الاتفاقيات على المستوى الدولي.

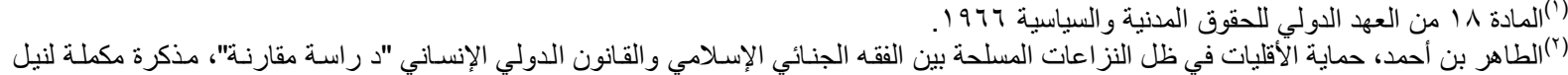

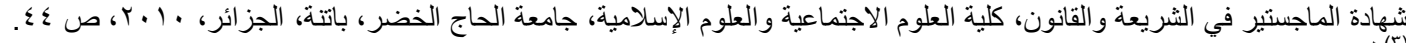

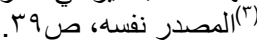

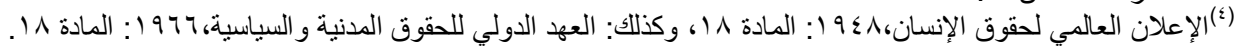




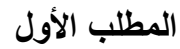 \\ المسؤولية القانونية لحماية الأقلية الاينية الاولية}

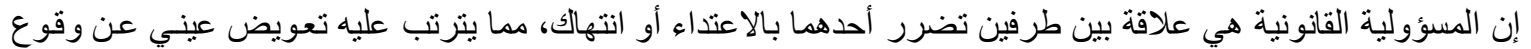

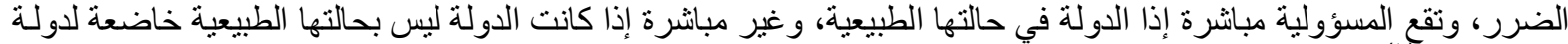

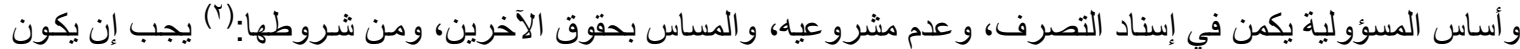

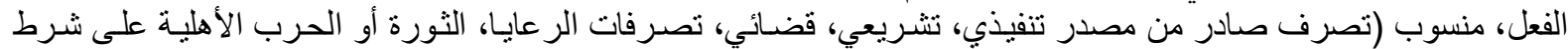

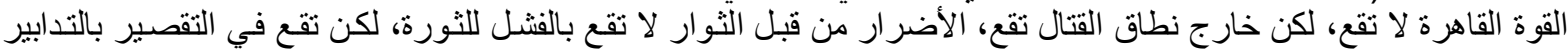

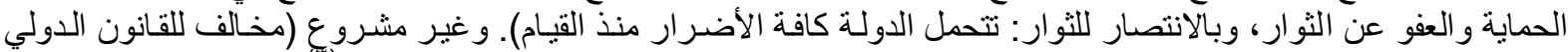

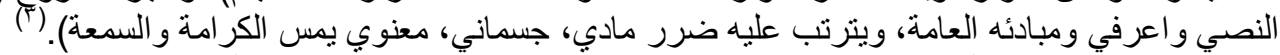

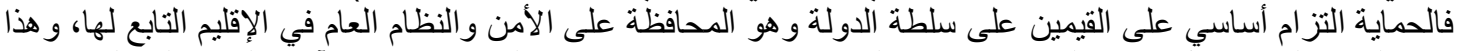

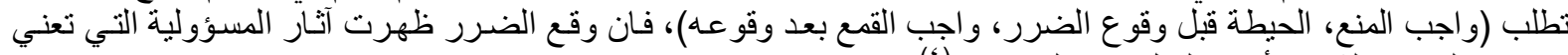

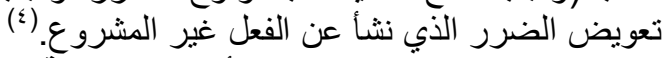

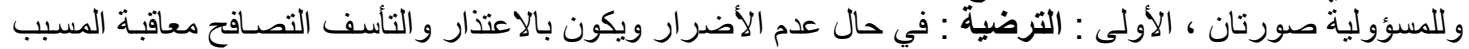

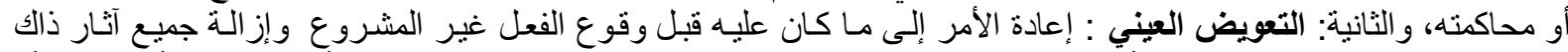

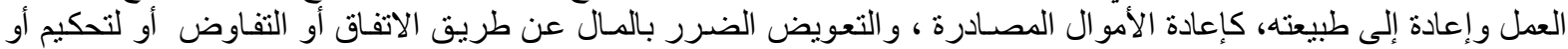

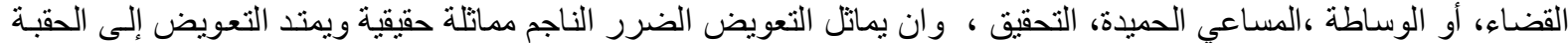

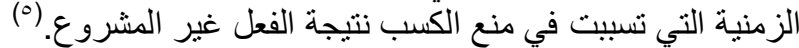

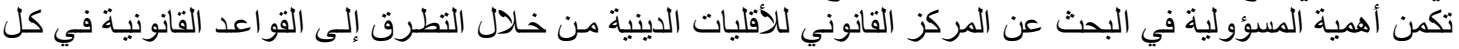

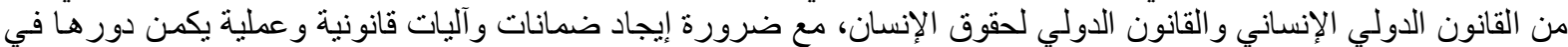

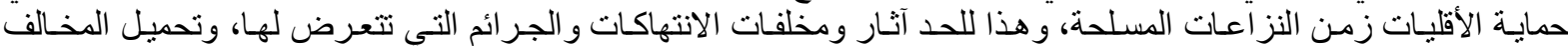

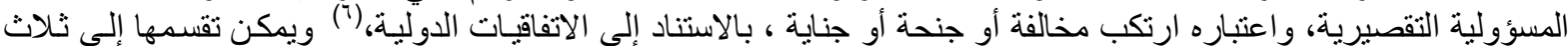

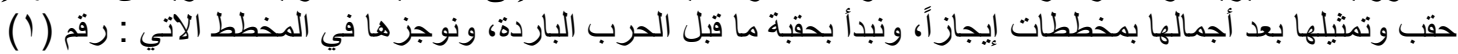

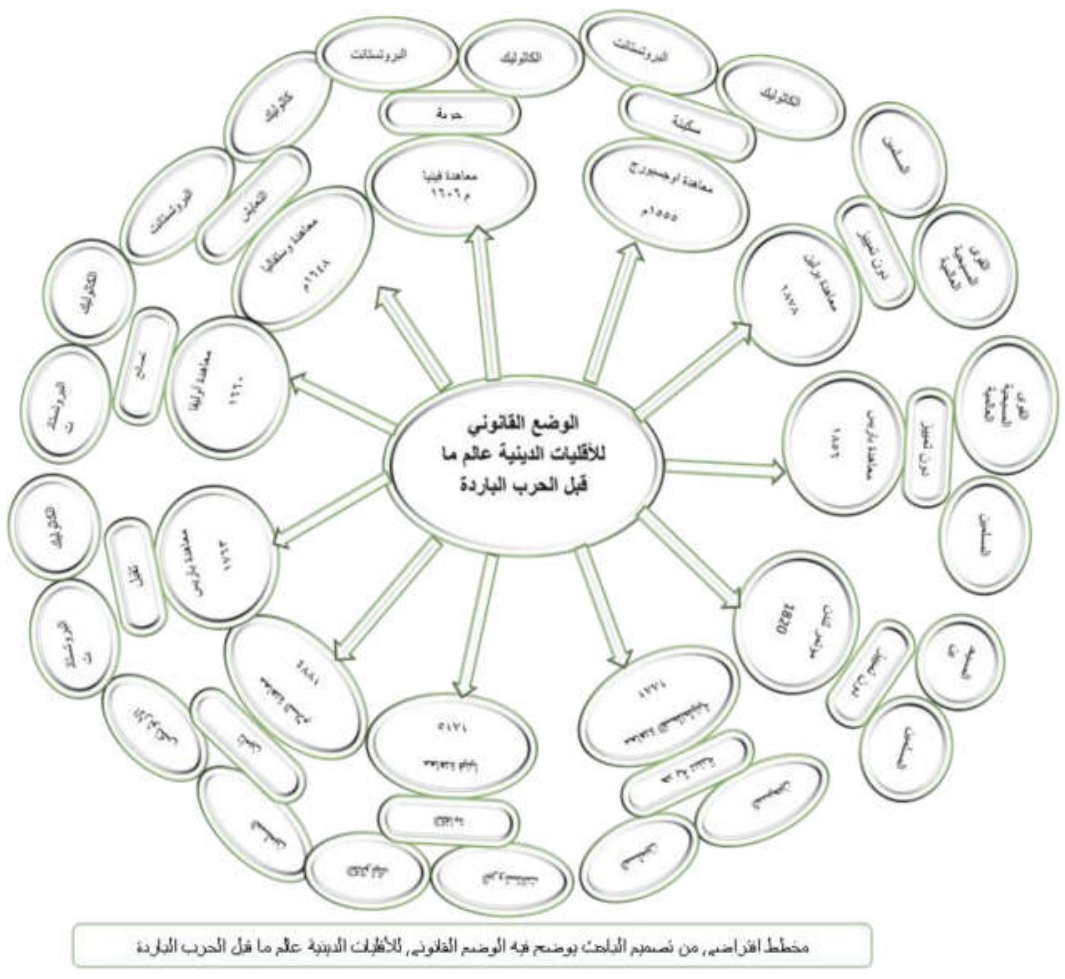

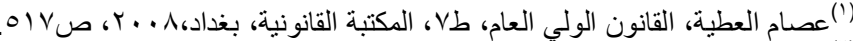

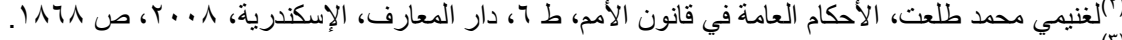

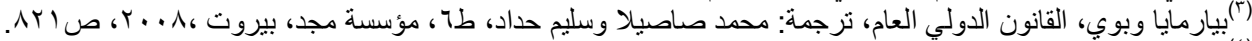

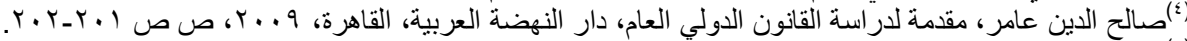

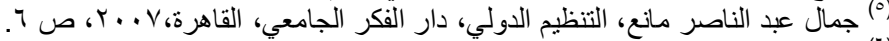

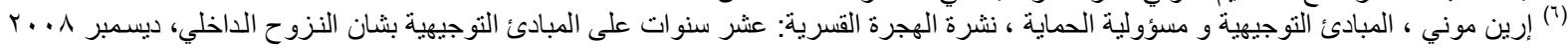


وحقبة الحرب الباردة وما حملت من مواثيق دولية نوجز ها بالمخطط الاتي: رقم ( r)

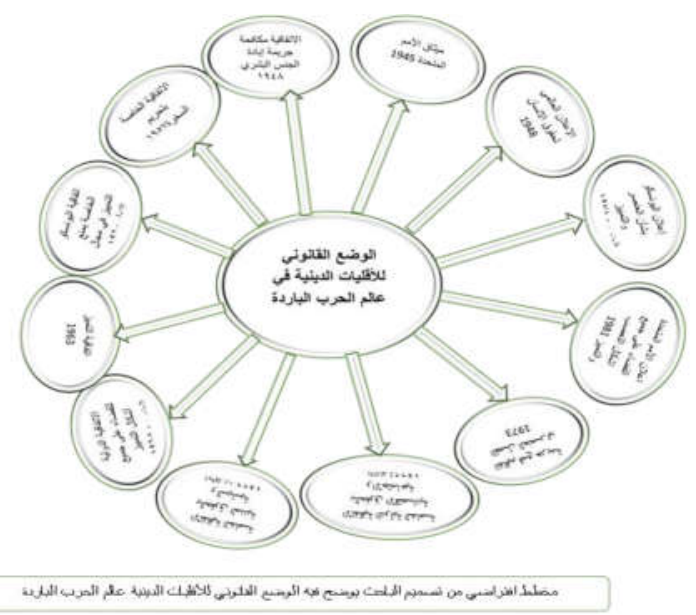

وحقبة ما بعد الحرب الباردة وما صدر عنها من مواثيق دولية مهمة وفاعلة نوجزها بالمخطط الاتي: رقم ( r)

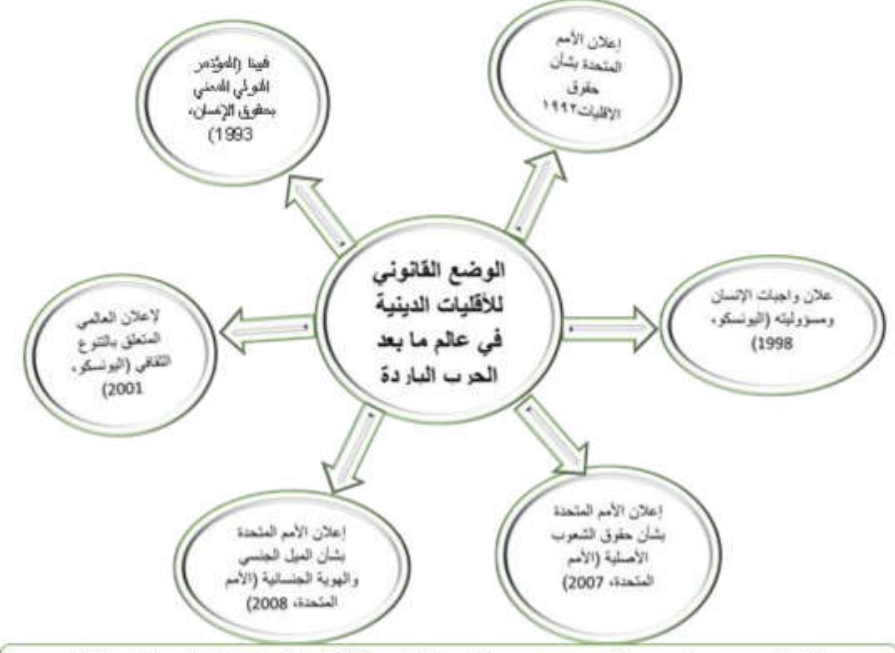

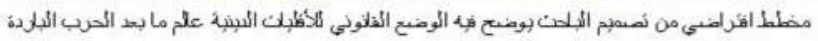

\section{المطاب الثاني}

آليات حماية الأقليات الاينية في النزاعات المسلحة

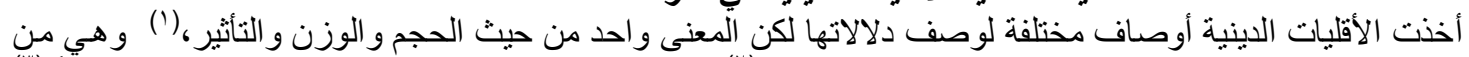

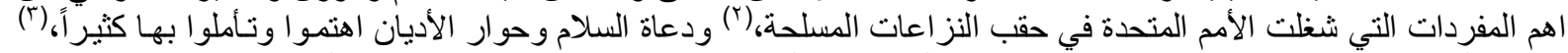

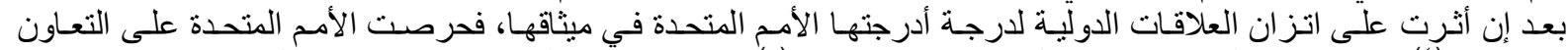

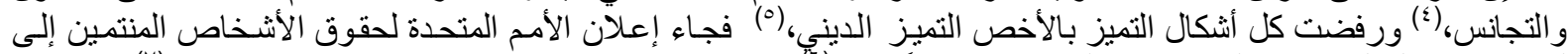

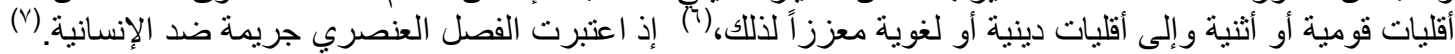

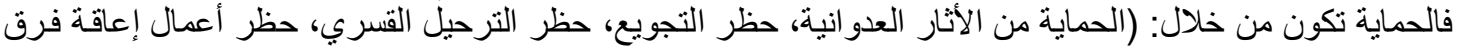
الإغاثة، حظر الاعتداء الجسدي وأعمال الثرف، حظر الاعتداء على الثئ دور العبادة ومنع الثُعائر الدينية، حظر الإبادة الجماعية). و هذه الضمانات لكي تكون فعالة يتطلب الاتي:

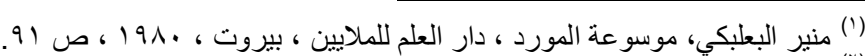

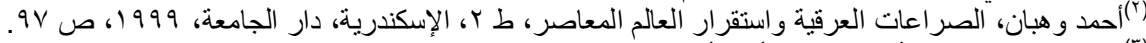

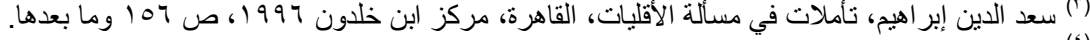

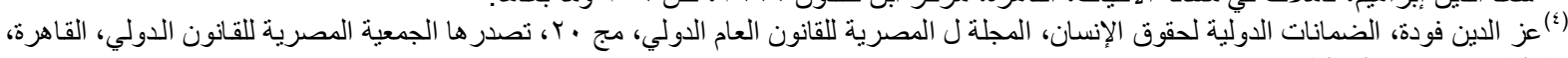
. 19 - 9 .

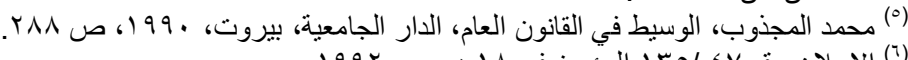

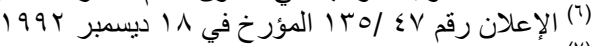

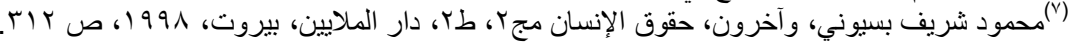




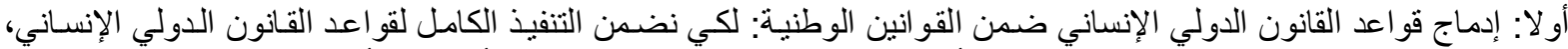

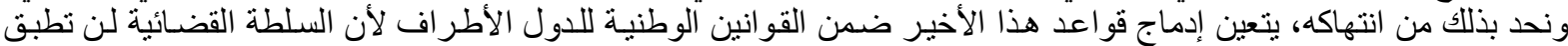

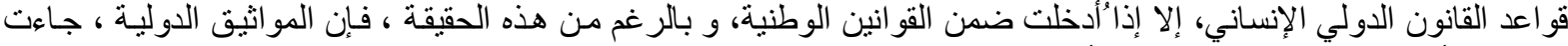

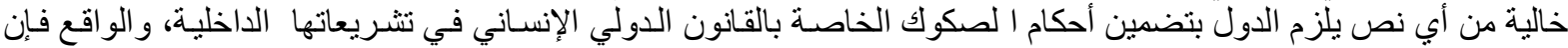

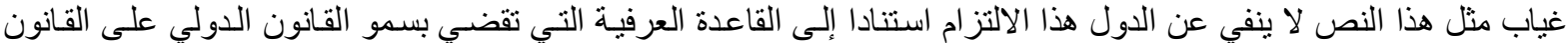

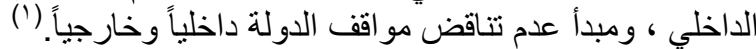

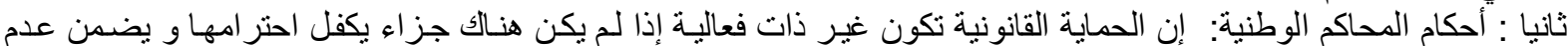

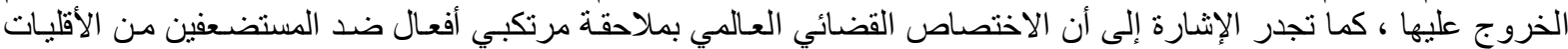

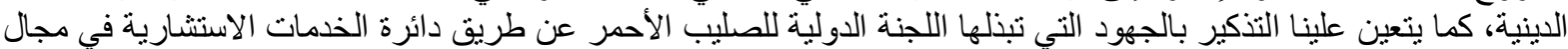

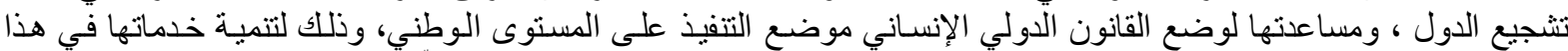

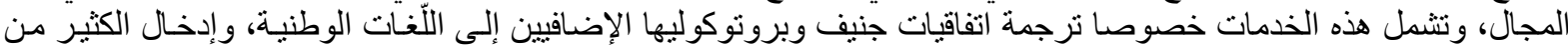

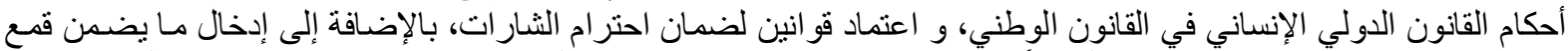

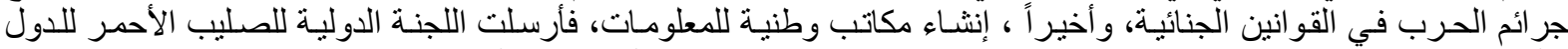

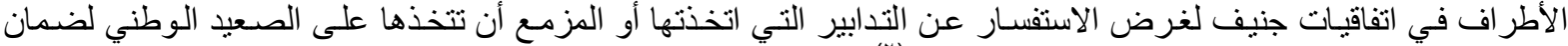

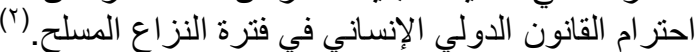

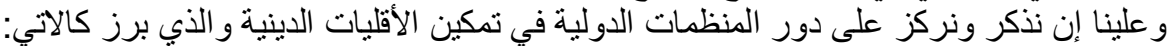

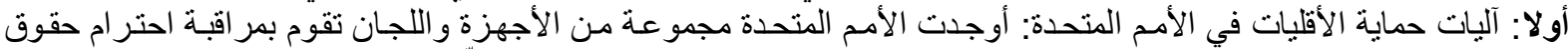

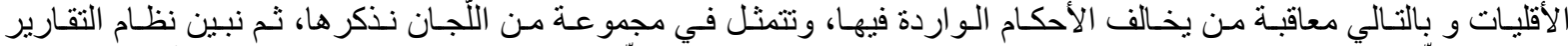

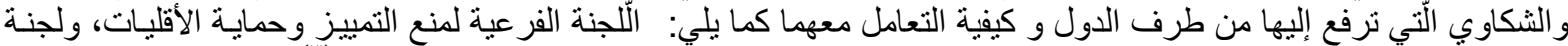

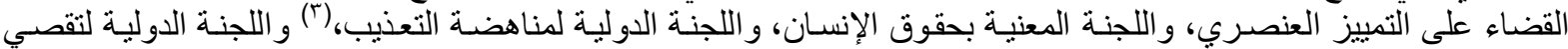

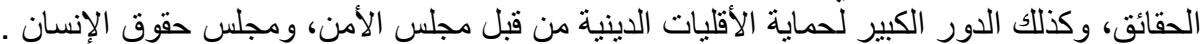

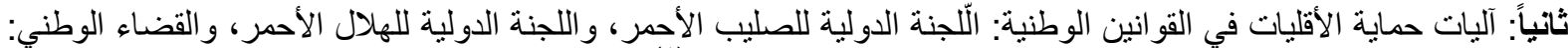

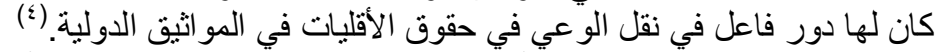

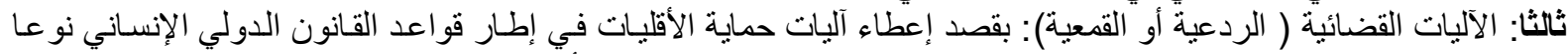

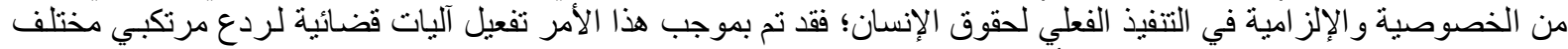

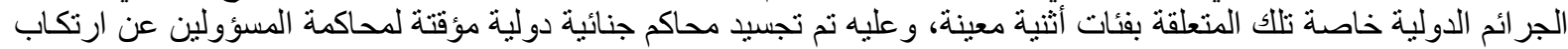

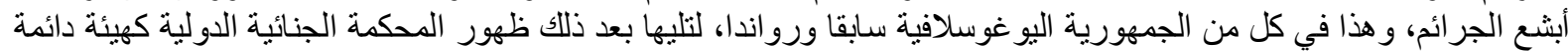
مختصة في هذا الثأن.

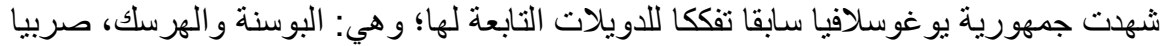

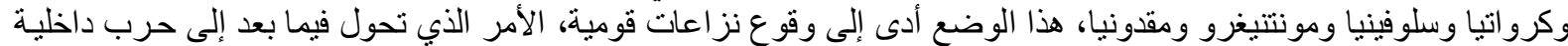

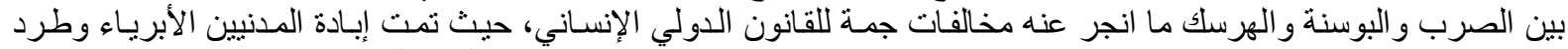

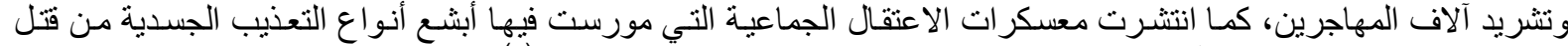

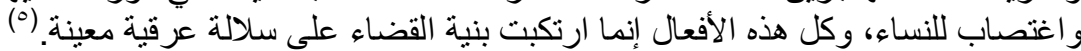

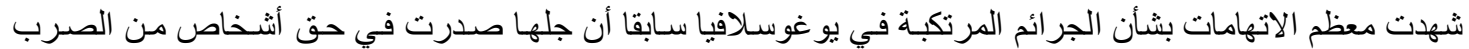

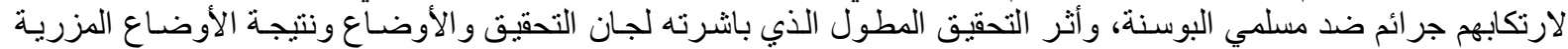

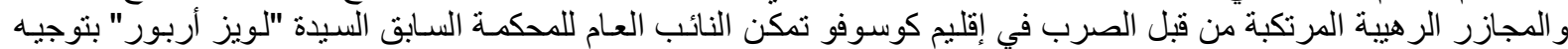

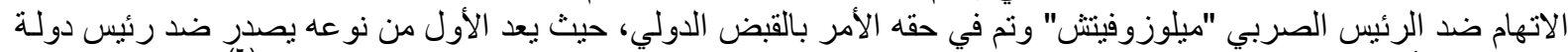

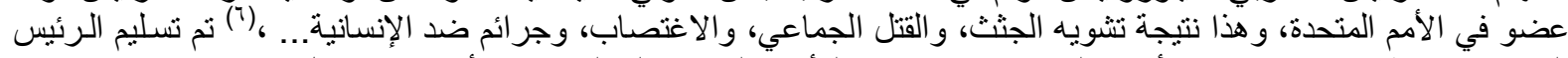

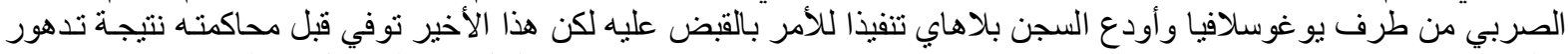

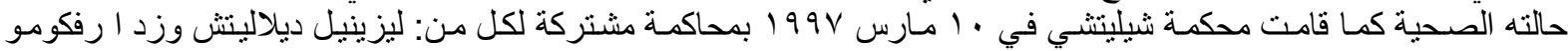

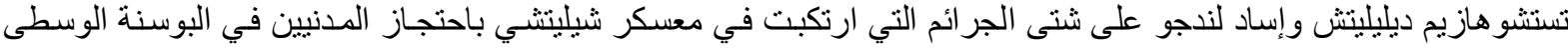

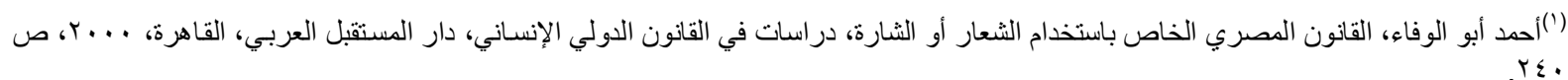

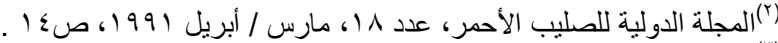

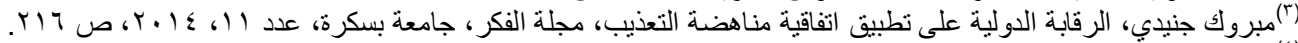

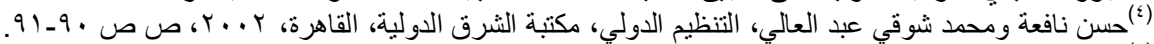

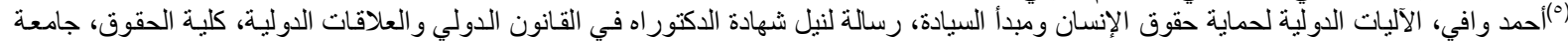

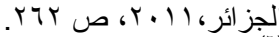
(جاج سامية زاوي، دور مجلس الأمن في تطبيق القانون الدولي الإنساني، رسالة لنيل شهادة الماجستير في الحقوق، قسم القانون العام، كلية الحقوق، جامعة

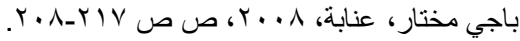




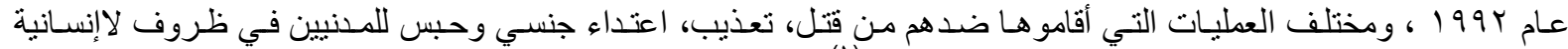

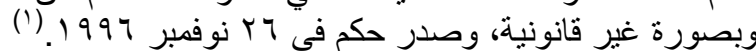

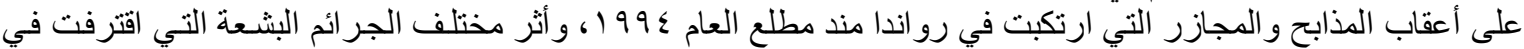

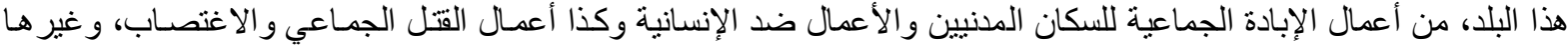

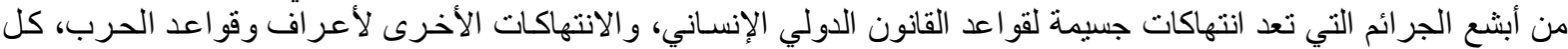

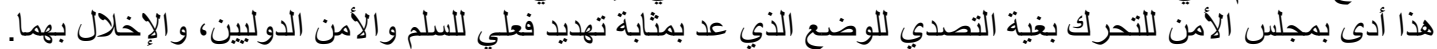

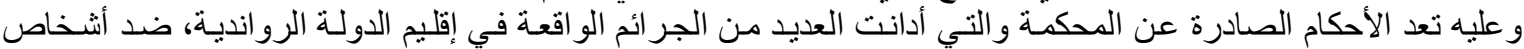

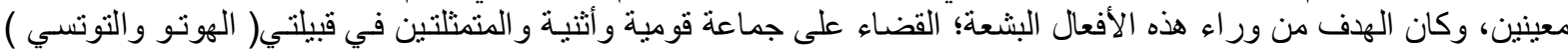

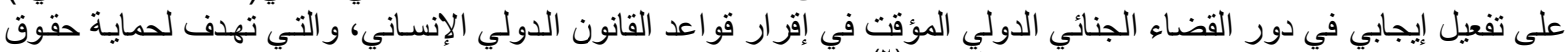

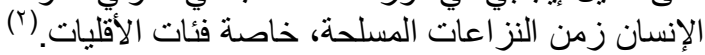

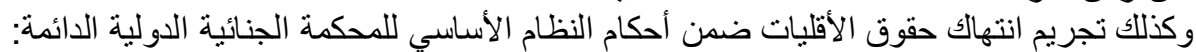

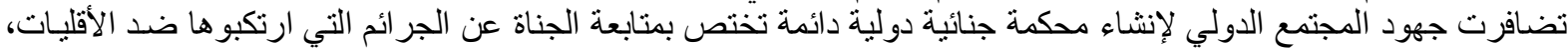

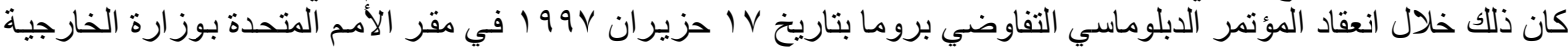

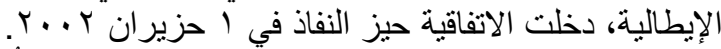

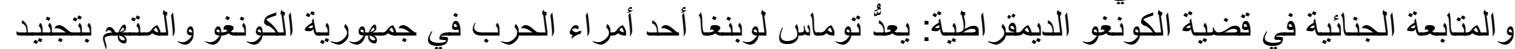

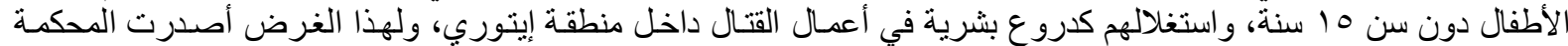

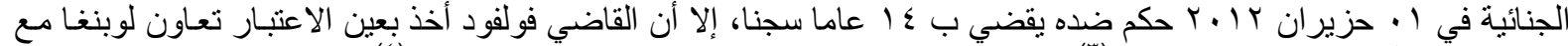

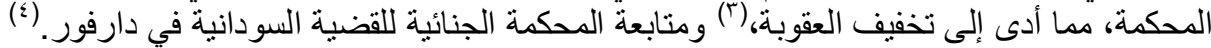

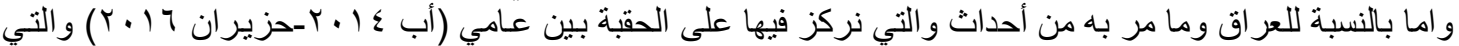

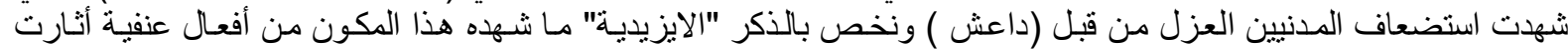

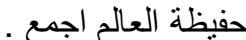
السؤال هنا : هل ارتقت أفعال( داعش) إلى جريمة الإبادة الجماعية للمكون الايزيدي؟ وفقاً لبنود مجلس الأمن الدولي وقو انين

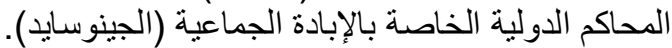

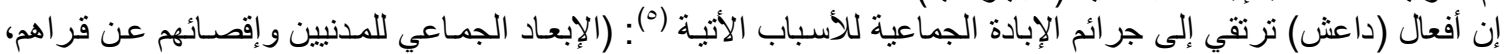

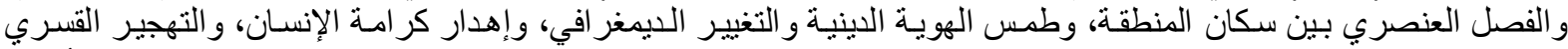

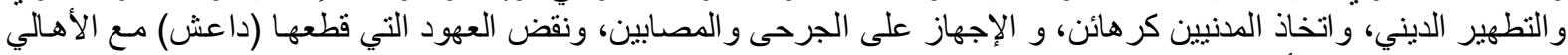

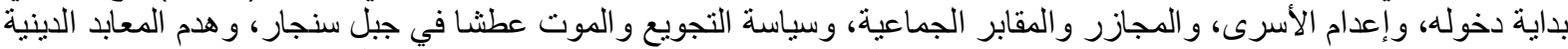

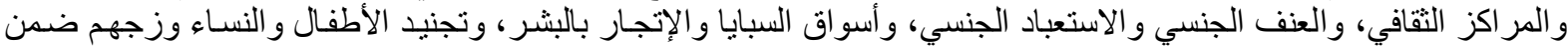

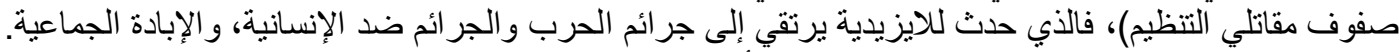

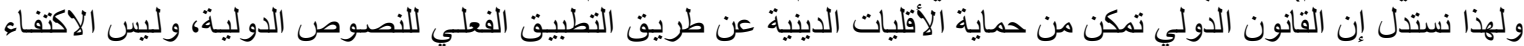

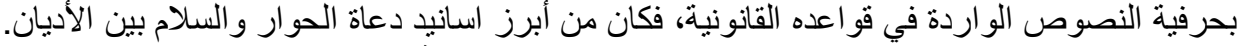

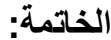

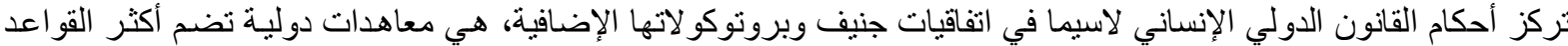

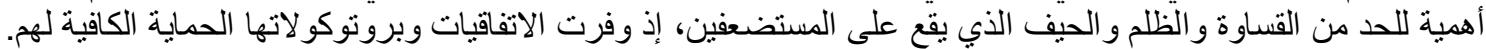

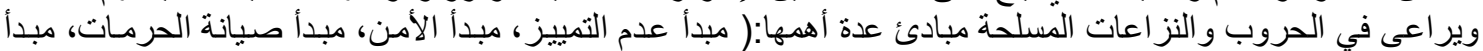

التناسب بين مفهومين متعارضين وهما ولين الإنسانية و الضرورة العسكرية، مبدأ التفرقة بين المدنيين و العسكريين.

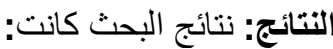

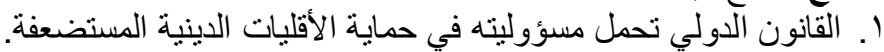

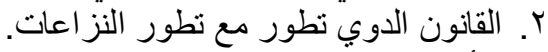

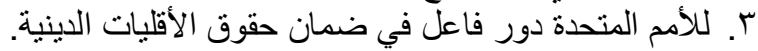

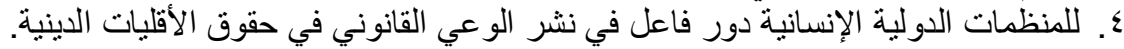

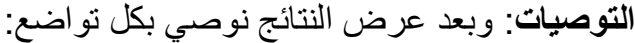

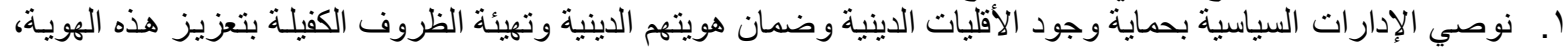
واعتماد التدابير التشريعية والقضائية والتنفيذية الملائمة لتحقيق تلك الغاينة التيات.

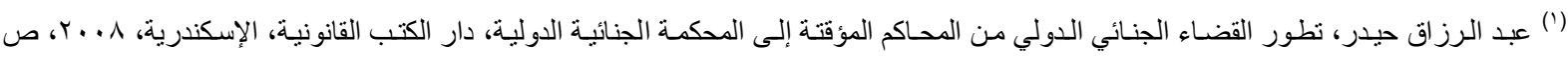

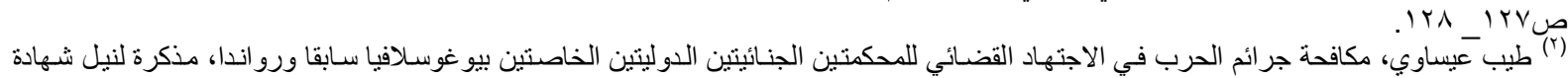

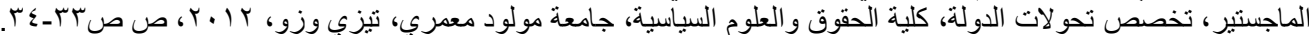

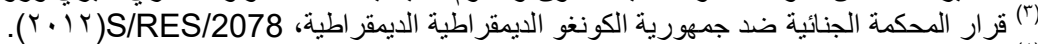

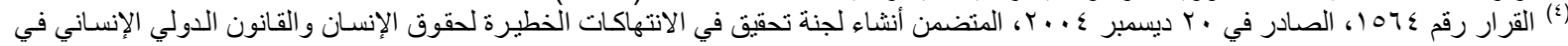

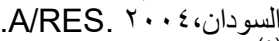
(o) داود مر اد ختاري ، الإبادة الجماعية الإيزيدية وفق القو انين الدولية، محاضرة في مركز الدراسات الايزيدية / في البيت الايزيدي اولدنبورك/ المانيا 


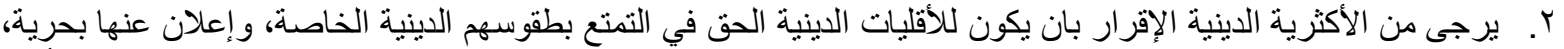

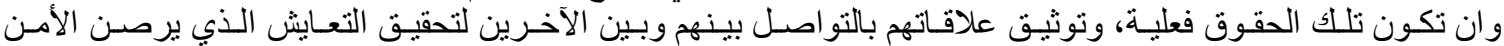

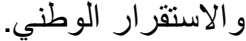
r. ينطلب من الإدارات السياسية اتخـاذ كافة التدابير الاحترازيـة لحمايـة أماكن التواجد الأقليات الدينية ودور العبادة وتيسير ممارسة الطقوس الدينية.

ع. ضرورة اتخاذ التدابير الأمنية الاستباقية من قبل الفئات المتناز عة التي تضمن امن وسلامة الأقليات الدينية المستضعفة.

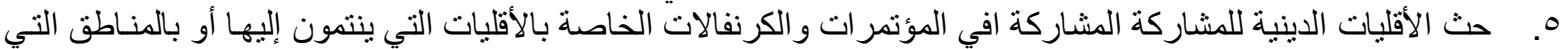

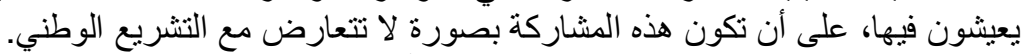

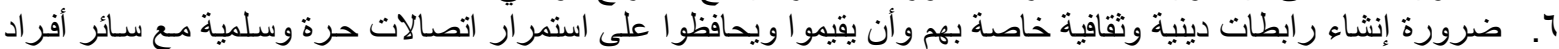

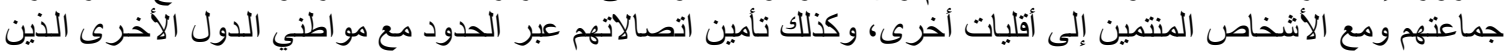
تربطهم بهم صلات دينية دون أبي تمييز.

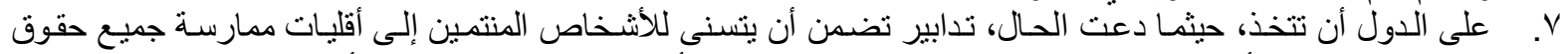

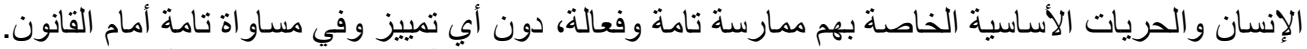

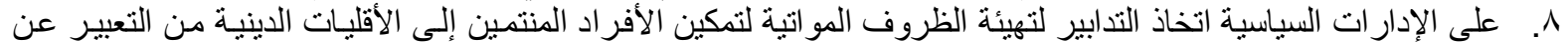

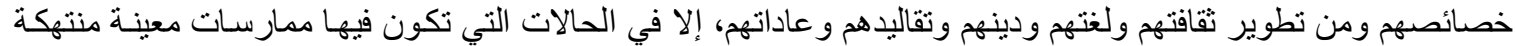
للقانون الوطني ومخالفة للمعايير الدولية.

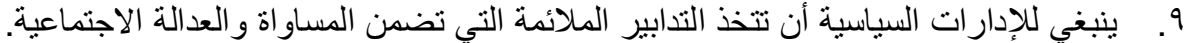

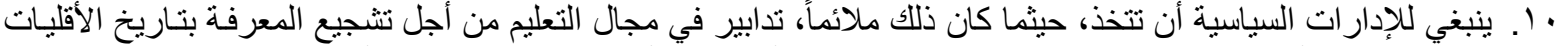

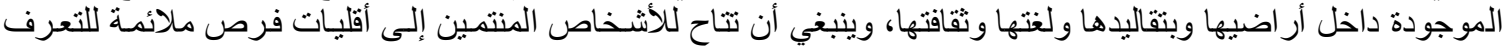

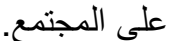
ا'. ينبخي على الإدار ات السياسية أن تنظر في اتخـاذ التدابير الملائهـة التي تكفل للأشخاص المنتمين إلى أقليات أن يثـاركه

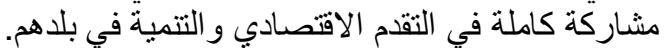

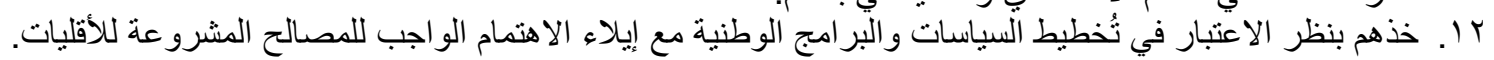

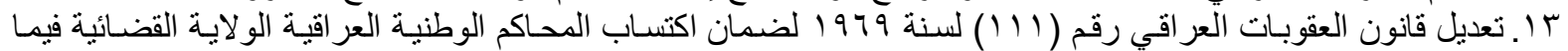

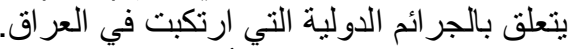

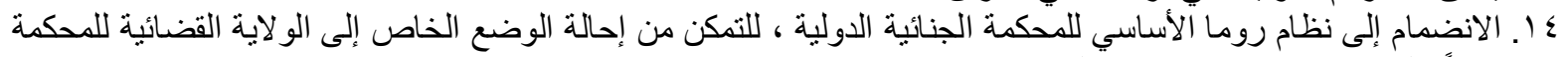

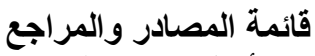
عملاً بالمادة رقم (r ( - ف فـ) من النظام. القرآن الكريم: ( سورة النساء، سورة الأعر اف، سورة الأنفال، سورة القصصادر).

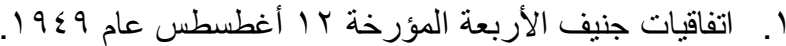

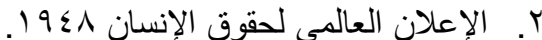

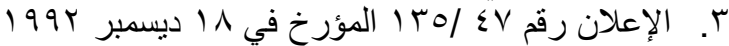

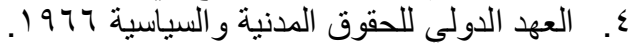

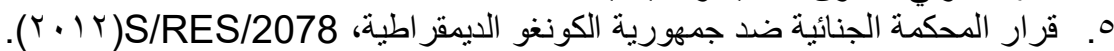

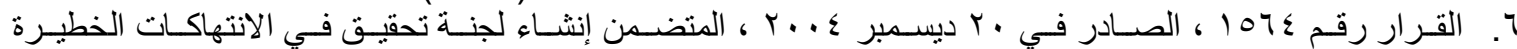

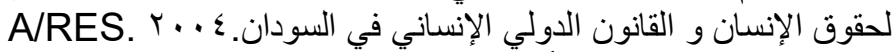

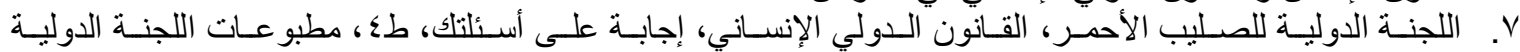

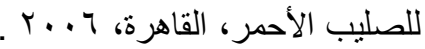

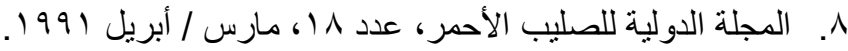
ثنانياً الكتب :

ا. . أبو نصر إسماعيل بن حماد الجو هري الفار ابي، لصحاح تاج اللغة وصحاح العربية، تحقيق: أحدد عبد الغفور عطار،

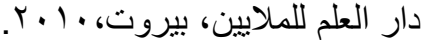

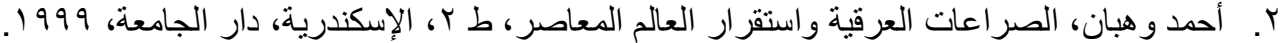

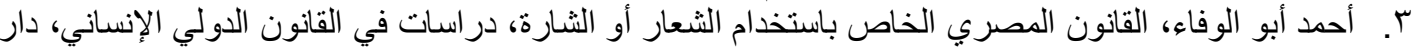

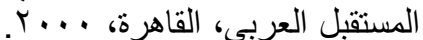
ع. بدرية عقعاق، مفهوم الأقليات في القانون الدولي و الوسائل الدولية لحمايتها، الطبعة الأولى، دار الفكر والقانون

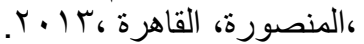

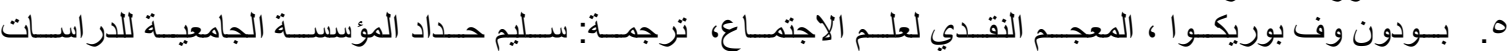

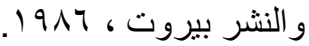

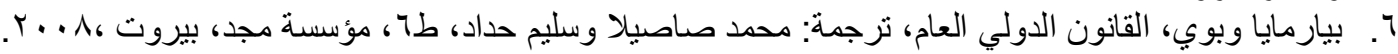

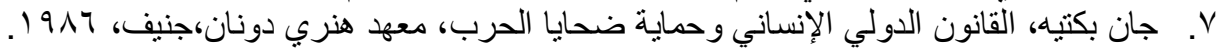




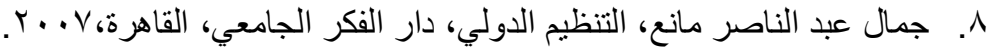

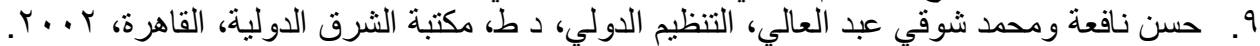

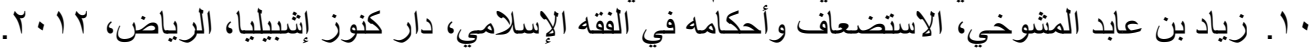

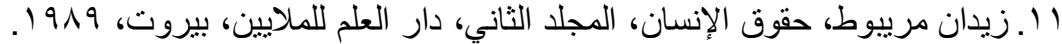

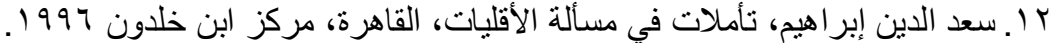

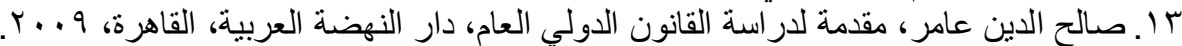

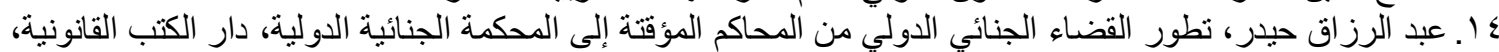

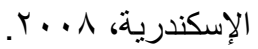

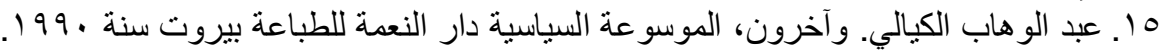

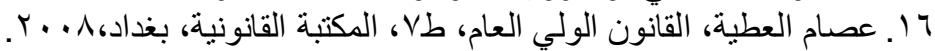

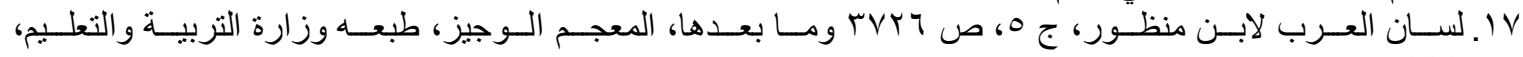
.1991

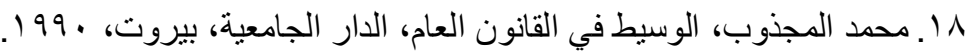

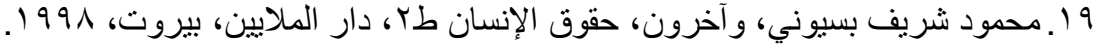

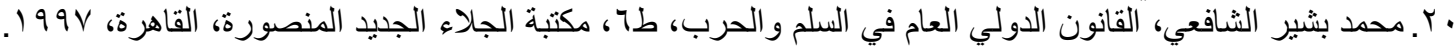

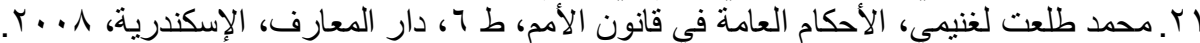

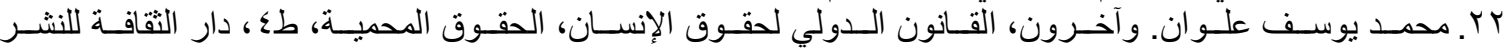

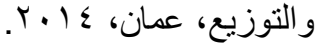

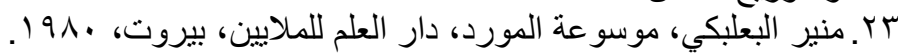

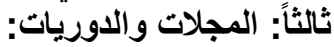

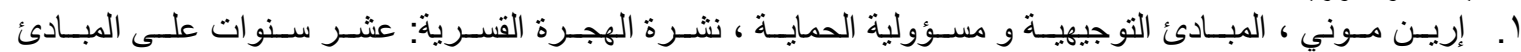

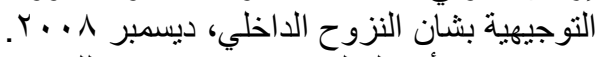

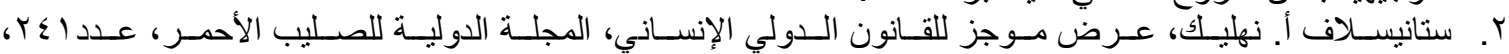

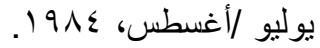

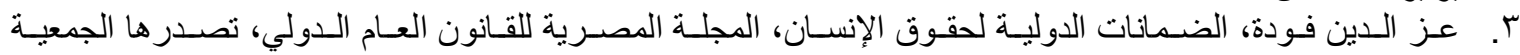

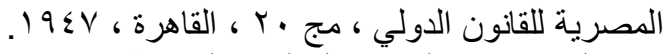

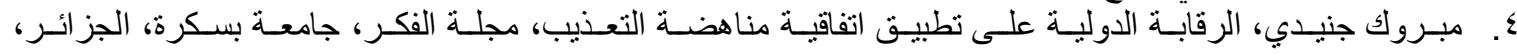

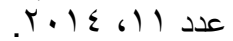

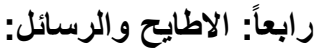

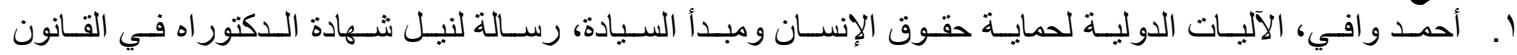

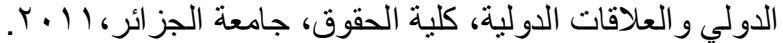

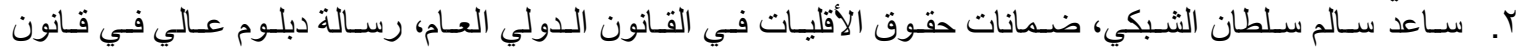

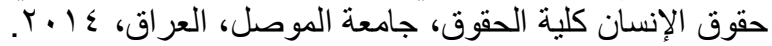

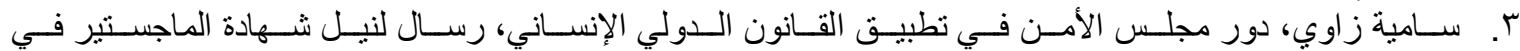

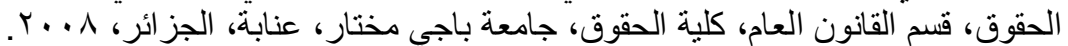

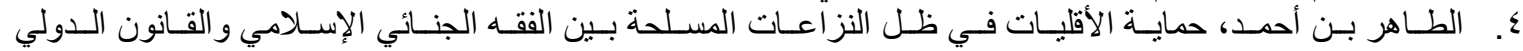

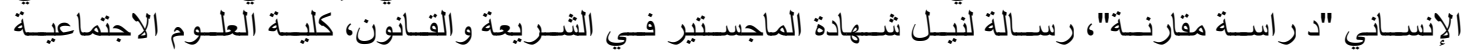

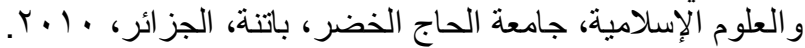

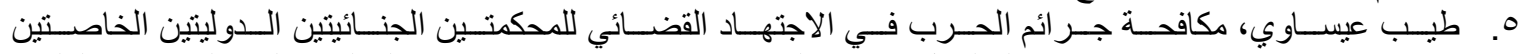

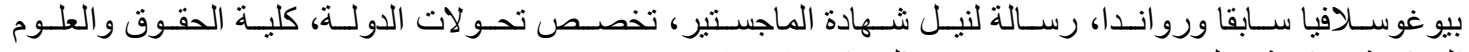

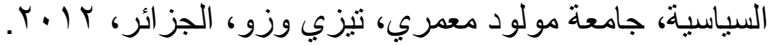

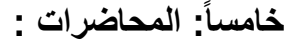
ا ـ داود مر اد ختاري ، الإبادة الجماعية الإيزيدية وفق القو انين الدولية، محاضرة في مركز الدراسات الايزيدية / في البيت

\section{الملخص}

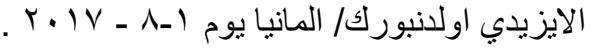

يركز البحث على أهمية حماية الفئات الدينية المستضعفة، و التعريف بها وبيان دور القانون الدولي في ضمانة التهان حمايتها،

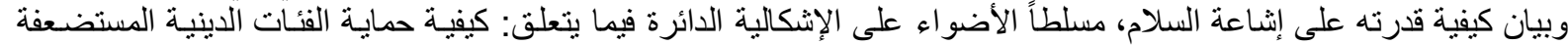

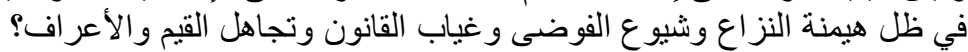

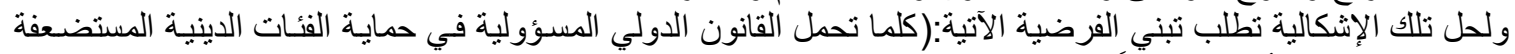

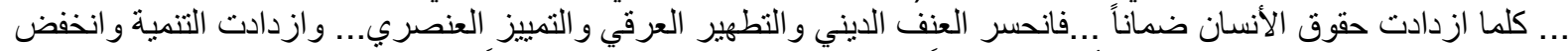
الفقر وتحققت البيئة الصالحة لتعايش الأديان )، وحلاً للإشكالية و إثباتا للفرضية، وتحقيقاً لمتطلبات البحث، استخدمنا المنهجان 


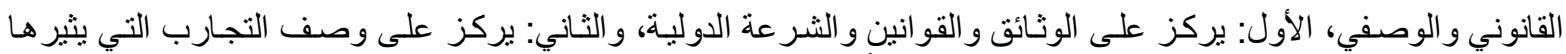

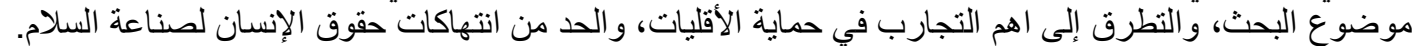 الكلمات المفتاحية (القانون الدولي، الفئات الدينية المستضعفة، حقوق الأنسان، التعايش، السلام). \\ Abstract}

The research focuses on the importance of protecting vulnerable religious groups, identifying them and showing the role of international law in ensuring their protection and demonstrating how they can promote peace, highlighting the problematic aspects of how to protect vulnerable religious groups under the domination of conflict, chaos and lawlessness?

In order to solve that problem, the following hypothesis is required: "Whenever international law bears the responsibility to protect vulnerable religious groups ... the more human rights are guaranteed ... religious violence, ethnic cleansing and racial discrimination will be reduced ... development has increased, poverty has fallen, The second focuses on the description of the experiences raised by the subject of the research, and on the most important experiences in the protection of minorities and the reduction of violations of human rights. Man for the Peace Industry.

Keywords: International Law, Vulnerable Religious Groups, Human Rights, Coexistence, Peace. 